\title{
Archaeological Examination of Japanese Photographs and Archival Data from the Pre-WWII Okinawan Diaspora: Tinian, Commonwealth of the Northern Mariana Islands
}

\author{
Boyd Dixon $^{1} \cdot$ Alexandra Garrigue $^{2} \cdot$ Robert Jones $^{3}$ \\ Accepted: 21 September 2020/Published online: 21 October 2020 \\ (C) Springer Science+Business Media, LLC, part of Springer Nature 2020
}

\begin{abstract}
This study looks at archival records and photographs from the pre-WWII Japanese occupation of the Micronesian island of Tinian to discuss the archaeological remnants of the Okinawan diaspora from the 1920s to 1940s in the Commonwealth of the Northern Mariana Islands (CNMI) today.
\end{abstract}

Keywords Pre-WWII $\cdot$ Okinawa $\cdot$ Diaspora $\cdot$ Tinian

\section{Introduction}

Examination of early twentieth-century archival photographs, textual documents, maps, oral histories, and archaeological remains in this study converge to create a picture of a well-managed, corporate plantation with government subsidies on Tinian, on the Northern Mariana Islands. This perspective brings the Northern Mariana Islands into the forefront of pre-WWII industrial and urban development during a depression devastating the Japanese homeland and global economy, much as we are experiencing in the twenty first or "Covid" century today. Emigration from Okinawa, rural Japan,

Boyd Dixon

dixonboyd@hotmail.com

Alexandra Garrigue

alex@arcgeo.jp

Robert Jones

Robert.jones@cardno-gs.com

1 Cardno GS, 425 Chalan San Antonio Rd., PMB 1004, Tamuning, Guam 96913, USA

2 ARCGEO, 901-2215 Okinawa-ken, Maehara 3-17-2, Yuai Bld 1F, Ginowan-shi, Japan

3 Cardno GS, 250 Bobwhite Court, Suite 200, Boise, ID 83706, USA 
and Korea enabled tens of thousands of individuals and families to improve their standard of living and expectations for their next generations born on Tinian. Personal sacrifices were endured, loyalty to their Ryūkyū homelands and family was stretched, and efforts were made to make Tinian seem more familiar, indeed a "transported landscape" in many ways.

WWII brought an end to this dream and replaced it with a nightmare through which their families still in Okinawa suffered in subsequent months. The quantity and quality of documentary materials today found in academic and public libraries in Okinawa demonstrates that this story is not forgotten but is being told and retold within individual families. Repeat visits from Okinawa to Tinian every year also demonstrate that the Northern Mariana Islands were for a 30-year period of time, a very real part of Japan and the Ryūkyūs in the minds and hearts of a generation.

\section{The Okinawan Diaspora to the Northern Mariana Islands}

Although conducted in close parallel to the general Japanese diaspora, Okinawan emigration in the first half of the twentieth century bears several peculiar characteristics engendered by the political and social compartments, of which the prefecture was the object in the colonial Japanese Empire. The Ryūkyū Kingdom officially came under Japanese government rule in 1879 with the creation of Okinawa Prefecture, but kept a special status within the empire, Okinawans only obtaining the right to vote in 1912, for instance. In such a context, many rules

and laws related to the emigration of Japanese citizens were not immediately applied to the residents of Okinawa Prefecture.

Okinawan emigration can be divided into eight periods, four of them occurring before WWII (Ishikawa 1974, 2005, 2011). Starting in 1921, emigration toward the Nanyō Islands increased when Japan took over administration of the archipelago and created a development company known as the Nanyō Kōhatsu. As a result of this, the number of persons of Okinawan origin in the southern islands reached 15,000 in 1932 (57\% of the Japanese migrants). With the flourishing of Nanyō emigration until WWII, this proportion reached $70 \%$ just before the Pacific War.

\section{Historical Context: Administration of the Nanyō Islands by Japan}

The Mariana Islands (except Guam) used to be a part of the German colonial empire (German Protectorate of New Guinea) and were seized by the Japanese Forces during WWI. The German colonial empire was dismantled after WWI as a part of the Treaty of Versailles (1919) and the islands fell under the control of the newly created League of Nations (1920) that created the South Pacific Mandate. This authorized the administration of the islands north of the equator, including the Mariana Islands, Palau, Marshall Islands, and Micronesia (Fig. 1), by the Japanese Empire starting on December 17, 1920. By that time, Japan had occupied the Northern Mariana Islands since 1914 and had shifted the administration of the Mariana Islands from a military to a civil one. The South Pacific Mandate was referred to as the Nanyō (Southern Seas) Archipelago in Japanese and the Nanyō Office (Southern Seas Office) was established 
in 1922 to administer all the islands in the mandate. Japanese emigration toward the Nanyō archipelago was organized at that time.

The Nanyō Office started with six branches with a detached office of the Saipan Branch in Tinian by 1933 (Tuggle 2014). The Japanese started to develop the Nanyō Islands during the military administration before the establishment of the Nanyō Office with two companies called Nishimura Colonization (sugar and manufacture) and Nanyō Investments (sugar and Manilla hemp). Nanyō Investments collapsed in 1920 and Nishimura Colonization in 1921, leaving on the islands 1000 Japanese workers

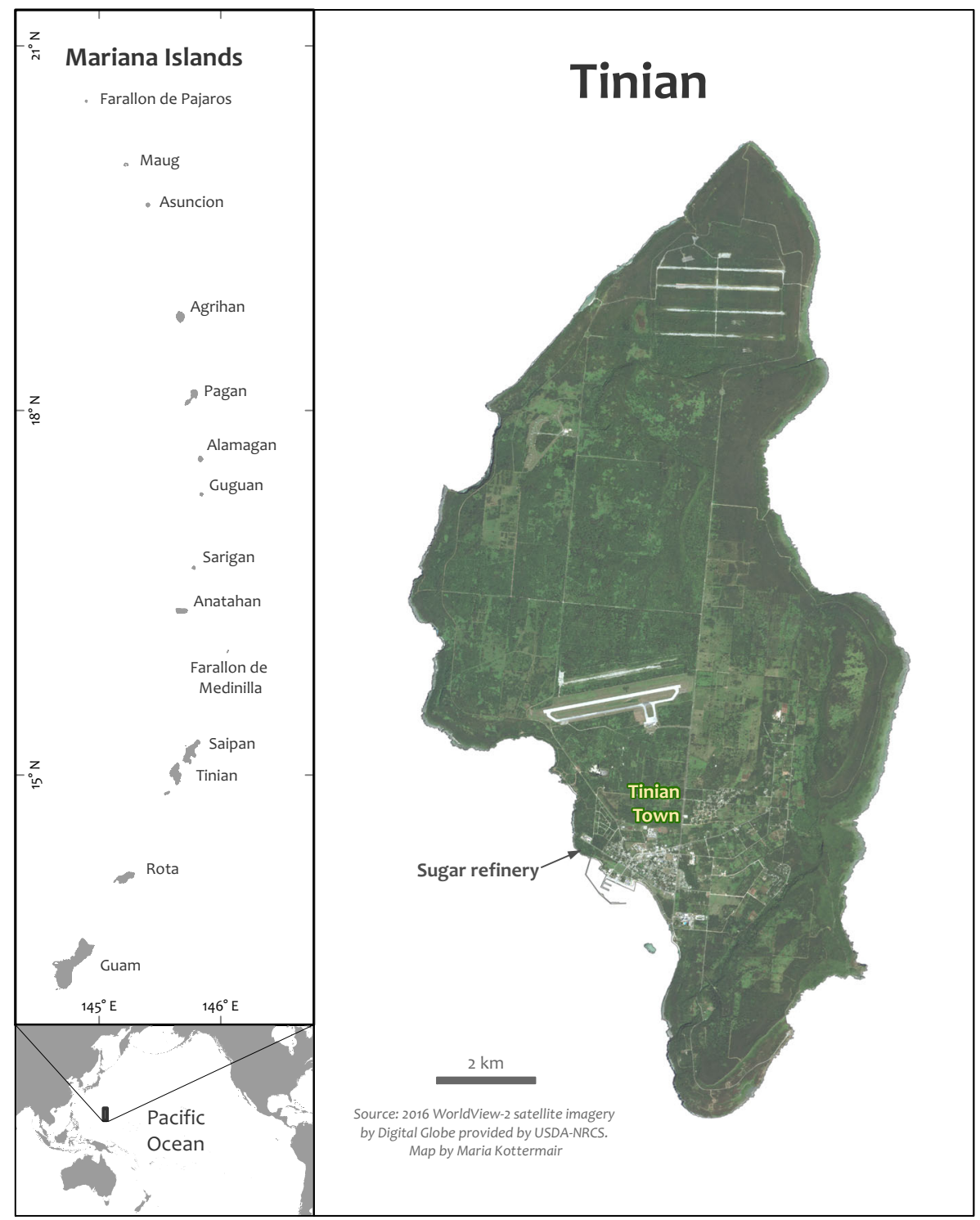

Fig. 1 Location of Tinian within the Commonwealth of the Northern Mariana Islands (Courtesy of Maria Kottermair) 
who started starving. Tezuka Toshirō, the first governor of the Nanyō Office recognized the abilities of Haruji Matsue (Fig. 2). He was then working on sugar manufacture development in Taiwan and was particularly invested in the welfare of Japanese emigrants and the development of sugar manufacture techniques. Matsue then met Ishizuka Eizō who was director of the very successful Oriental Development Company based essentially in Manchuria. Matsue and Ishizuka were both born in samurai families of the Aizu Domain in Fukushima and got along well enough for Ishizuka to agree to fund $70 \%$ of a new development company entrusted to Matsue, Nanyō Kōhatsu Kaisha (NKK).

Matsue bought the two previously mentioned collapsed companies and in addition to the 1000 workers already on the islands, he asked the government to send 2000 Okinawan workers to start developing the Nanyo Islands to extend Japan's power southward. Matsue explained that he chose to ask for Okinawans due to their proximity, the overpopulation problem of the prefecture, the fact that Okinawans were generally willing to try their chance abroad, and that for many of the 1000 workers already in the Nanyō Islands, the Ryūkyū Islands were their home. Moreover, Okinawans were versed in sugar cane agriculture and used to the tropical climate (Matsue 1932:82). Matsue adopted new techniques developed by German researchers

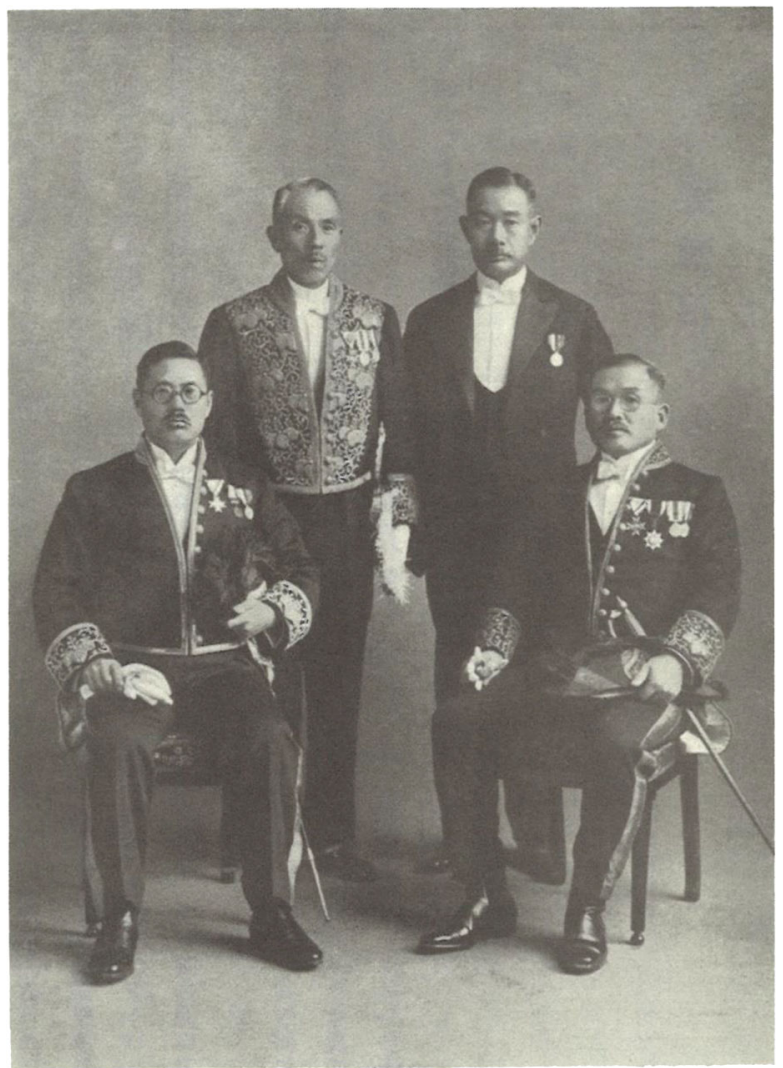

Fig. 2 Personnel of the Saipan Bureau in Ceremony in the Presence of Emperor Hirohito. [Haruji Matsue Standing to the Right] (Matsue 1932:160). Translated from Japanese 
in sugar production and started the construction of $50 \mathrm{~km}$ of railroad to ease transportation.

The Saipan Sugar Factory predating Matsue's involvement was operational as soon as 1923 , but the sugar cane fields were devastated by insects, and the fact the railway was not yet completed on the island largely hindered production. Moreover, 1923 was the year of the Great Kantō Earthquake, and the sugar that had been produced and sent to Yokohama was destroyed in the disaster. The investment of more money in the Nanyō Island was highly criticized at the time, but Matsue imported insect resistant sugar cane plants from the Philippines and developed a railroad network fast enough for the Saipan factory to be profitable as soon as 1925. The Nanyō Office accorded the monopoly in sugar cane production, sugar manufacture, and sugar trade in the Nanyō Islands to Nanyō Kōhatsu Kaisha, that developed into a gigantic company that accounted for $64 \%$ of the income produced under the administration of the Nanyo Office in 1932 (Iitaka 1999).

\section{Life in the Marianas}

Although the prosperity of Nanyō Kōhatsu Kaisha was grounded in sugar manufacture, it employed people in each stage of the production from the growing of sugar cane to the shipping of sugar bags to mainland Japan. It also diversified its activities as soon as the 1930s with a wide range of domains including fishery, agriculture, alcohol production, ore extraction, oil production, transport, and trade. At its apogee just before the war, it employed 48,000 persons. Saipan, Tinian, and the smaller island of Rota to the south (see Fig. 1) essentially produced sugar. Okinawan people were employed in each of those industries, but most of them worked in agriculture or fishing. A survey held in 1948 recorded the details of 3,952 persons who had come back to Okinawa from the Nanyō Islands after the war (Okinawa Culture Development Association 2002:675685), including the occupations in which they used to work, that are detailed in Table 1 below.

Table 1: Occupation and Number of Okinawans formerly Employed on Tinian

\begin{tabular}{llc}
\hline Occupation & & $\begin{array}{c}\text { Number of } \\
\text { persons }\end{array}$ \\
Agriculture & Tenant & 561 \\
& Employee & 996 \\
Fishing & Tenant & 100 \\
& Employee & 473 \\
Construction works & Tenant & 46 \\
& Employee & 217 \\
Trade & Tenant & 103 \\
& Employee & 26 \\
Government officials & & 229 \\
Others & & 1201 \\
\hline
\end{tabular}


Agriculture included people working in direct management farms under the direct control of the company, the land tenants who were attributed land parcels of diverse sizes and cultivated them for the company, and land tenant employees. Tenants who were attributed more than 6 ha generally employed farmers to cultivate the land and took care of other activities themselves, such as the raising of cattle or horses. Many fishermen were also dispatched to the Nanyō Islands: of the 6,719 Japanese fishermen accounted for in 1942, 6,164 were from the Ryūkyūs.

Socioeconomic mobility was possible. Iha Okimasa, a resident of Chatan whose parents emigrated to Saipan in 1922 (Iha 2006), explained that his father first came as a carpenter and then changed activities to build carts for the transportation of harvested sugar cane from the fields to the railroad before he became involved in agriculture. Asato Uto, who came as a bride to Tinian in 1937, explained that her husband started as an employee of a direct management farm, but was recruited by a tenant to work his land. He changed employers several times before he then became a land tenant (Asato 2002:97-100).

\section{Residences and Everyday Life}

A large variety of residences were built on the different islands. Asato Uto said she first lived in a common house for two families with a zinc roof when her husband worked for a direct management farm. Her husband then started to work for a tenant whose wife came from the same hamlet as him in Okinawa. She doted on him, and assigned them a house with concrete foundations and a zinc roof constructed in a corner of their farm premises. His employer recommended him to the Nanyō Kōhatsu Kaisha manager and he was assigned land that had been left by a man who had to go back to Okinawa. The land included a house with a concrete building, a large cistern, a pig pen, and a stable. Unless stated otherwise, Okinawa refers to the main island of the Ryūkyū chain and not the prefecture.

At the beginning of the 1920s, the daily wages for a manual worker in Saipan reached 1 yen and 10 sen (1/100 of one yen) while they were only receiving 30 sen in Okinawa (Asato 2002). At this time the yen was valued at approximately \$0.30 American and continued to drop by WWII (https//en.wikipedia.org/wiki/ Japanese_yen). The money for sugar cane was paid to the tenants on the following year, supposedly because the board of directors of Kōhatsu was in Tōkyō and the money had to be sent from the mainland. When Asato Uto and her family took over the land of the person who had to come back to Okinawa, they received the money this man had earned the previous year (370 yen). The prizes for "particular accomplishments" her husband regularly won for his good work were of 3 or 5 yen so that 370 yen represented a large amount of money for their first year as independent tenants. On the other hand, in 1943 and 1944, due to the war, they did not receive any money.

The life of the small farmers in the Mariana Islands detailed by Iha Okimasa and Asato Uto is generally similar to the one described by people who lived in Okinawa at the same period. Children on Tinian went to harvest grass for the cattle every day after school and took care of the pigs and goats, eating wild melons and watermelons growing in the fields, catching shrimp in the rivers (not on Tinian) and shellfish in 
the sea. Farmers grew vegetables for their own use, collected and sold firewood to increase their income, and produced household manure for their fields.

Life was easier than in Okinawa since the wages were higher. Asato Uto said they could eat rice every day for breakfast, lunch, and dinner while in Okinawa they only ate rice in the evenings, the other meals being made of sweet potatoes. Most accounts from Okinawan people living in Okinawa at the same time agree that rice was not part of the common diet. For celebrations, people in the Nanyo Archipelago ate beef and goat, and drank awamori, a traditional rice wine that was made by Okinawan people in Tinian. There were soba noodle restaurants (that were particularly popular in Okinawa as well) and distractions included theaters giving Okinawan plays and even a cinema hall (Asato 2002:100). The economy in Okinawa meanwhile continued to be depressed for all but the landed nobility and Japanese merchant class, as the impending war gradually consumed much of East Asia and its resources.

In anticipation of the war, a battalion of 1200 Japanese convicts was brought to Tinian in 1939 and a garrison of 8350 men was eventually stationed on the island to operate its defensive gun positions (Denfeld 1983). Two airfields were built, at Ushi to the north and at the present airport location, and a third was started at Kahet to the west. Around these airfields, barracks and administrative buildings were built, as well as defensive anti-aircraft batteries. Native Japanese and labor from Korea and Okinawa were forced to work on military construction projects day and night (Russell 1995). The influx of Japanese troops also brought housing pressures to the island. Schools were closed and used to house new troops, while students were put to work. By the war years of 1941 to 1944 sugarcane refining for sugar ceased in the Northern Mariana Islands and cane was diverted to Japan for the production of alcohol fuel (Russell 1983), while civilian laborers were relegated to military defenses with no wages and little time to grow their own food.

After the war, the US Forces mandated evacuation of almost all the Asian immigrants on Tinian in 1946. According to Asato Uto, they started with the Japanese, and that Okinawans were the last to leave the islands. Uto said that Okinawans were told they could stay, but very few of them chose this option. She went by the thirteenth ship. They reached Okinawa Island in one week. Only the Okinawans who had emigrated to the Nanyō Islands (and survived) came back to the Ryūkyūs after the war: most of the other emigrants in US allied countries such as in Latin America stayed in their new country. Currently the fourth or fifth generation of descendants of those emigrants still cultivate strong links with their mother islands in the Ryūkyūs (Matayoshi 2009). After the war, food, clothes, and even cattle were sent from the emigrants and their descendants to the devastated Okinawa Prefecture.

\section{Okinawan Emigration Elsewhere before and after WWII}

The growth of Tinian between 1932 and 1941, coincided with the last period of pre-war South American emigration. There were no South American documents located in this study for the period between 1932 and 1934. However, from 1935 to 1941 a total of 17,745 Okinawans emigrated abroad generally.

Starting in 1934, Brazil fixed a quota on the total number of immigrants allowed, so that immigration from Okinawa declined as early as 1935. On the other hand, 
emigration toward the Philippines increased, reaching a peak of 2584 persons in 1937. Likewise, emigration toward Singapore and Indonesia increased, and even the number of people going to Hawaii suggests a slight rebound after 1936.

From 1939, the Japanese government imposed an emigration policy to both Manchuria and Okinawa Prefecture. They sent 99 youth in 1939, 58 in 1940, and 50 in 1941 for the Manchuria Development Youth Brigades. A total of 200 households were also sent in 1940 as members of the Manchuria Development Group; it is unclear if Okinawa also had youth brigades.

The period between 1942 and 1947 corresponded to a break in the emigration flux abroad due to WWII. Emigration resumed in 1948 with people sent to South America, first toward Argentina and then primarily to Brazil and Bolivia. After 1963, the number of emigrants drastically decreased, only reaching a few hundred or a few dozen per year (Matayoshi 2009).

\section{The Tinian Plantation and Refinery}

Perhaps the best example of a combined Japanese company plantation town and sugar refinery was located on the island of Tinian (Ono and Ando 2007; Tuggle 2014). The island is not far south of Saipan, and very few native islanders remained after the arrival of the Japanese (Ono et al. 2002). Along the west coast at the location of a protected harbor, NKK established a company town, modeled after one founded in 1917 on Minami Daito, a small Japanese island east of Okinawa (Ono et al. 2002).

Songsong, the former San Halon fishing village, became Tinian Town in 1933 with a sugar refinery (Fig. 3), post office, warehouse, railway sheds, administrative offices, fish market, ice storage building, clubhouse, dispensary, canteen, and about 70 company houses (Peattie 1988; Myers and Peattie 1984; Russell 1983). Also operated by Okinawans were an awamori bottling shop (Fig. 4), a beer brewery (Figs. 5 and 6), and a smithy outside of town (Fig. 7) as well as eating and drinking establishments (Welch and Bodner 2014). By 1930, NKK had imported laborers, many from Okinawa, cleared land for sugarcane plantations (Fig. 8), helped organized alcohol factories, constructed Shinto shrines, and built railroads to the wharf and into the sugar mill by 1930 (Fig. 9).

Tinian was divided into rectangular plots of 6 ha within four plantations or farms, three of which were "agricultural lands" leased by tenant farmers (Fig. 10), most of whom paid rent in sugarcane and labor (Higuchi 1998). The island also supported several rural villages, a cattle farm near Lake Hagoi, several manure composting facilities (Tuggle and Higuchi 2012), and a small company town in rural north Tinian (Tuggle 2014).

In addition, individual tenant-farmer housing compounds often reflected individual Okinawan designs (Dixon 2014) scattered through the fields, all tied together by the sugarcane railroad and field road system to the refinery (Farrell 2012). In 1944 the civilian population of Tinian was 17,900 with only 26 of those being native Chamorro; the majority of the population was Japanese, Okinawan, or Korean (Bowers 1950). "The anomalies involved in the social ranking of three fairly distinct classes that had emerged in Micronesia by the 1930s - main-island Japanese at the top, Okinawans and Koreans in the middle, and Micronesians at the bottom - served to increase the ambivalence of the indigenous populations toward Japanese immigrant communities" 


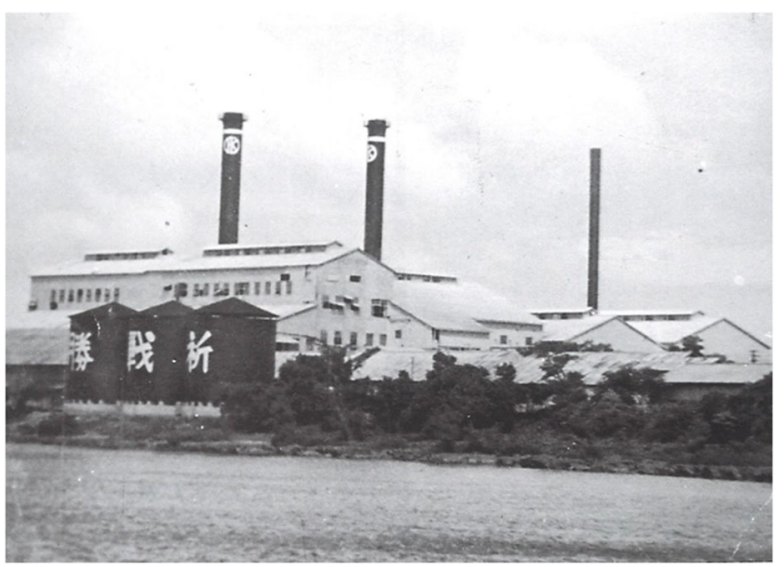

Fig. 3 Tinian Sugar Factory. Letters for Prayer for the War Victory Can be seen on the Tanks. (Okinawa Culture Development Association 2002:99). Translated from Japanese

(Peattie 1988:220). It appears the majority of Koreans were single laborers, with only the Okinawans and some Japanese farmers bringing family with them to settle with land leases.

\section{The Archaeology of the Sugar Plantation in Tinian Today}

Given that the shallow limestone-based clay soils in Tinian were not particularly rich in loam underneath, the removed jungle cover and the almost total lack of running water made irrigation an impossibility. Thus, the soils depleted over time without constant replenishing and fertilizing. Subsurface hoe scars have not been noted during limited excavations outside architectural remains in Tinian, nor have they been targeted for discovery. In contrast, such scars are routinely identified archaeologically in much deeper agricultural soils of Okinawa (Dixon et al. 2014). Planting and harvesting sugarcane on Tinian

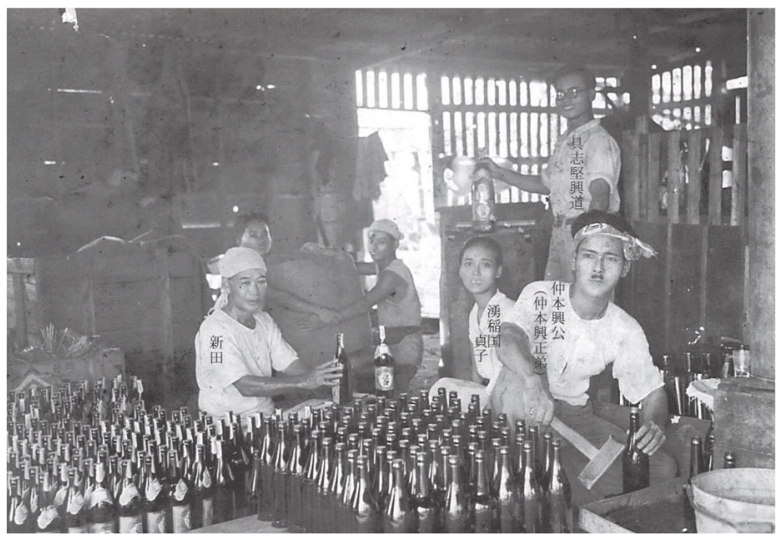

Fig. 4 Bottling Awamori in Recycled Beer Bottles (Okinawa Culture Development Association 2002:76). Translated from Japanese 


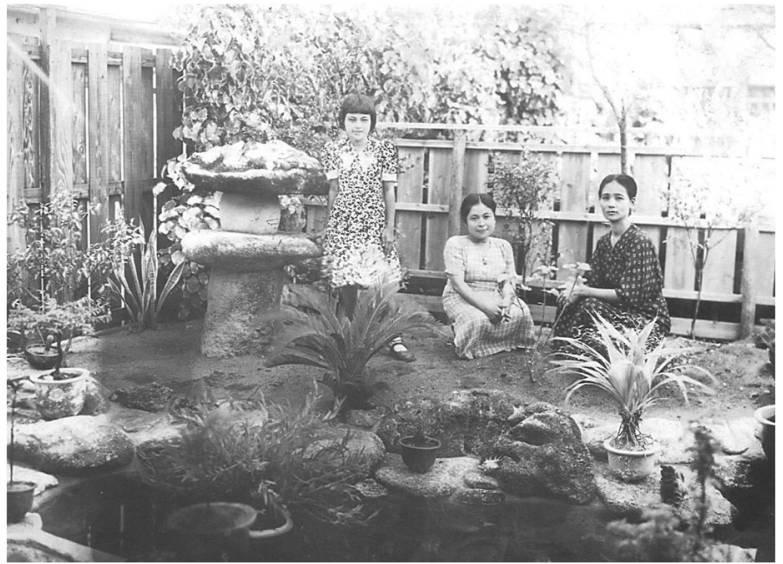

Fig. 5 Garden of Nakamoto Brewery (Okinawa Culture Development Association 2002:89). Translated from Japanese

plantations may not have required such individual labor or left their archaeological scars, if conducted by large groups of supervised field labor (see Fig. 8) or early mechanization.

Similar hand tools were utilized in both island groups, as recovered from archaeological contexts in middens at Tinian and in domestic Okinawan farmsteads, often near outdoor kitchens or concrete pigpens, latrines, and water catchment cisterns. Metal hoes and narrow-gauge railroad spikes, probably from the sugarcane fields, were recovered around household gardens and perhaps used for household repairs (Dixon 2004). They may well have been manufactured or modified by Mr. Kamiji's smithy (see Fig. 7). Fragments of porcelain serving ware, earthenware storage vessels, and glass bottles of beer, sake, awamori, and shoyu were often discarded at the edge of these rural dwellings (Dixon 2004), and many beverages may not have been imported but rebottled by the Oomini awamori and Nakamoto breweries (Figs. 4-6).

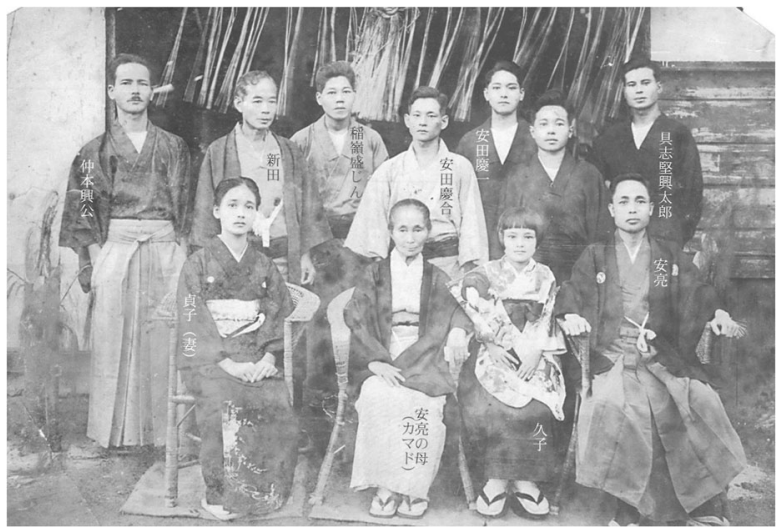

Fig. 6 New Year 1937 at Nakamoto Brewery (Okinawa Culture Development Association 2002:79). Translated from Japanese 


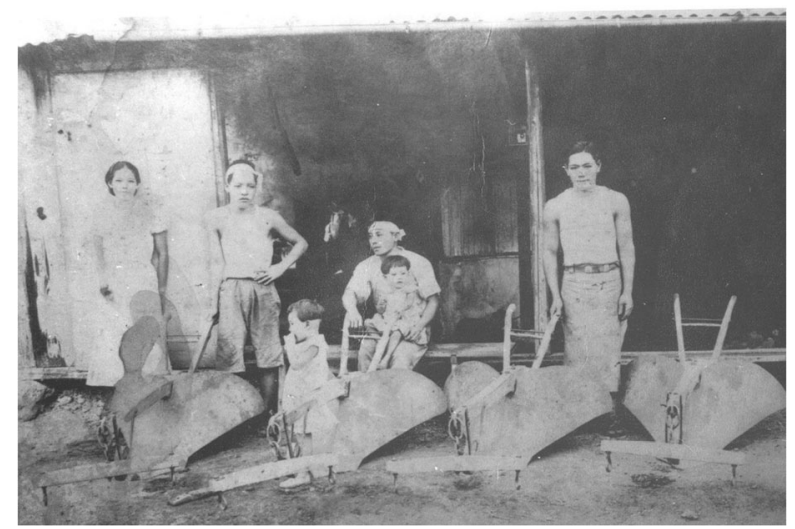

Fig. 7 Smithy run by (Okinawan) Mr. Kamiji in Kaahii District (Okinawa Culture Development Association 2002:181). Translated from Japanese

Also in rural Tinian, at least three large concrete manuring facilities have been archaeologically located in rural portions of the island near pig farms, signifying the recognition of the unsuitability of limestone island soils under pressure from the repeated cropping of sugarcane (Tuggle and Higuchi 2012). This observation by the closing years of the Japanese colonial enterprise in the late 1930s, has led some scholars to believe that reduced sugar production from soil depletion was already a serious problem in the Northern Marianas, only exacerbated by the ensuing war after 1941 (Tuggle 2014). The early sugarcane railroad system between distant fields and the sugar refinery (see Fig. 3). did not always access coastal areas of military defenses. But later spurs portrayed (see Fig. 10). and metal rails and flatbed cars recorded in the field (Dixon 2004) indicate that large camouflaged defensive guns and building materials such as concrete were likely transported directly to their construction loci from the port (see Fig. 9). (Denfeld 1983).

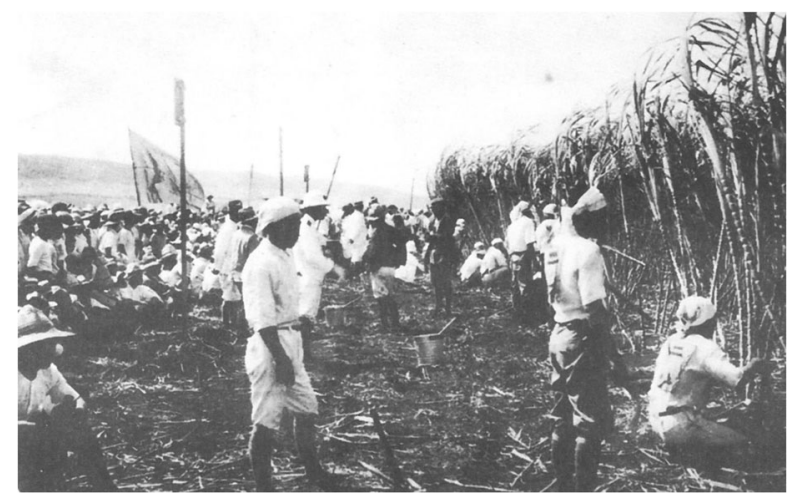

Fig. 8 Contest for the Sugar Cane Harvesting Probably like Okinawan Harusuubu Tradition of Agricultural Contests (Okinawa Culture Development Association 2002:151). Translated from Japanese 


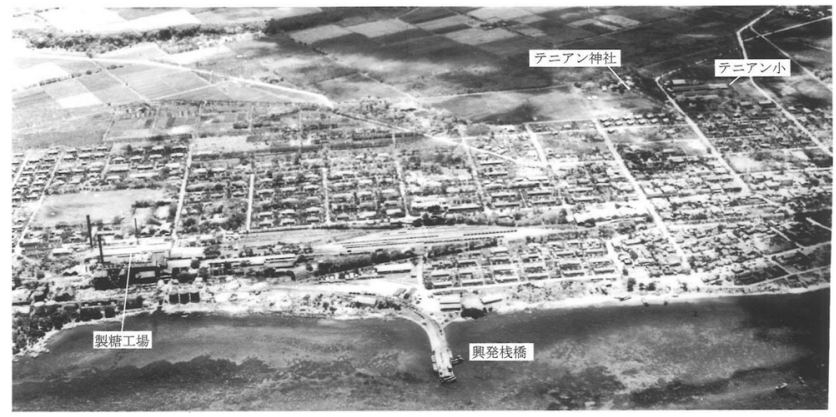

Fig. 9 Tinian Town Neighborhood of Nanyo Kohatsu Residential Area and Sugar Factory (Okinawa Culture Development Association 2002:16). Translated from Japanese

\section{Okinawan Farmsteads}

Much of the industrial and commercial architecture of Tinian Town was destroyed during the US invasion in 1944, then subsequently rebuilt to accommodate over 150,000 American military personnel until 1946. In contrast, many rural civilian Okinawan sites in areas such as the Carolinas plateau were left relatively undisturbed (Jones et al. 2019), except by combat. Sugarcane fields occupied $80 \%$ of the arable land on Tinian (Dixon 2004), so farmsteads occupied the main arteries and intersections of haul roads, or the margins of the fields and edges of cliff lines with little soil depth. They also served as defensive positions for Japanese soldiers as civilians retreated to more distant refuges.

Remnants of these Okinawan farmsteads included concrete water cisterns approximately $1 \mathrm{~m}$ deep by $1 \mathrm{~m}$ high and $2.5 \mathrm{~m}$ wide, originally with lids containing a covered entry and drainpipe apertures, plus an occasional low washing pad or platform. Concrete-walled pigpens kept this valuable asset secure and pigs were often fed from the family outhouse. Concrete house foundations or low pillars generally supported a wooden structure with a metal roof. In the case of site CHT-12, all these concrete remains were badly fragmented by shrapnel from artillery or aerial fire, alongside discards of the passing battle, including beer bottles (Fig. 11).

\section{Okinawan Gardens}

Several pairs of garden features were encountered near the farmstead in a relatively flat area under cultivation prior to the war. These features such as site CHT-10 consisted of small rectangular enclosures made by either a single or double course of local limestone boulders (Figs. 12 and 13). The interiors appear to have been cleared of large rocks, and the enclosures are $2-3 \mathrm{~m}$ to a side. Seemingly paired with each enclosure was an irregular depression, 1-3 $\mathrm{m}$ in diameter and 30-60 cm deep; one rock enclosure had two such pits within $3 \mathrm{~m}$. These low-walled enclosures would have been insufficiently tall to act as pens or foxholes of any kind, and hence are interpreted as stone-lined garden plots. 


$$
\text { テニアン島 }
$$

\begin{tabular}{|c|c|}
\hline \multicolumn{1}{|c|}{ 凡 例 } \\
○ & 農場事務所 \\
++ & 鉄道 \\
() & ラジオビーコン \\
文 & 学校 \\
「 & 送信所 \\
\hline
\end{tabular}

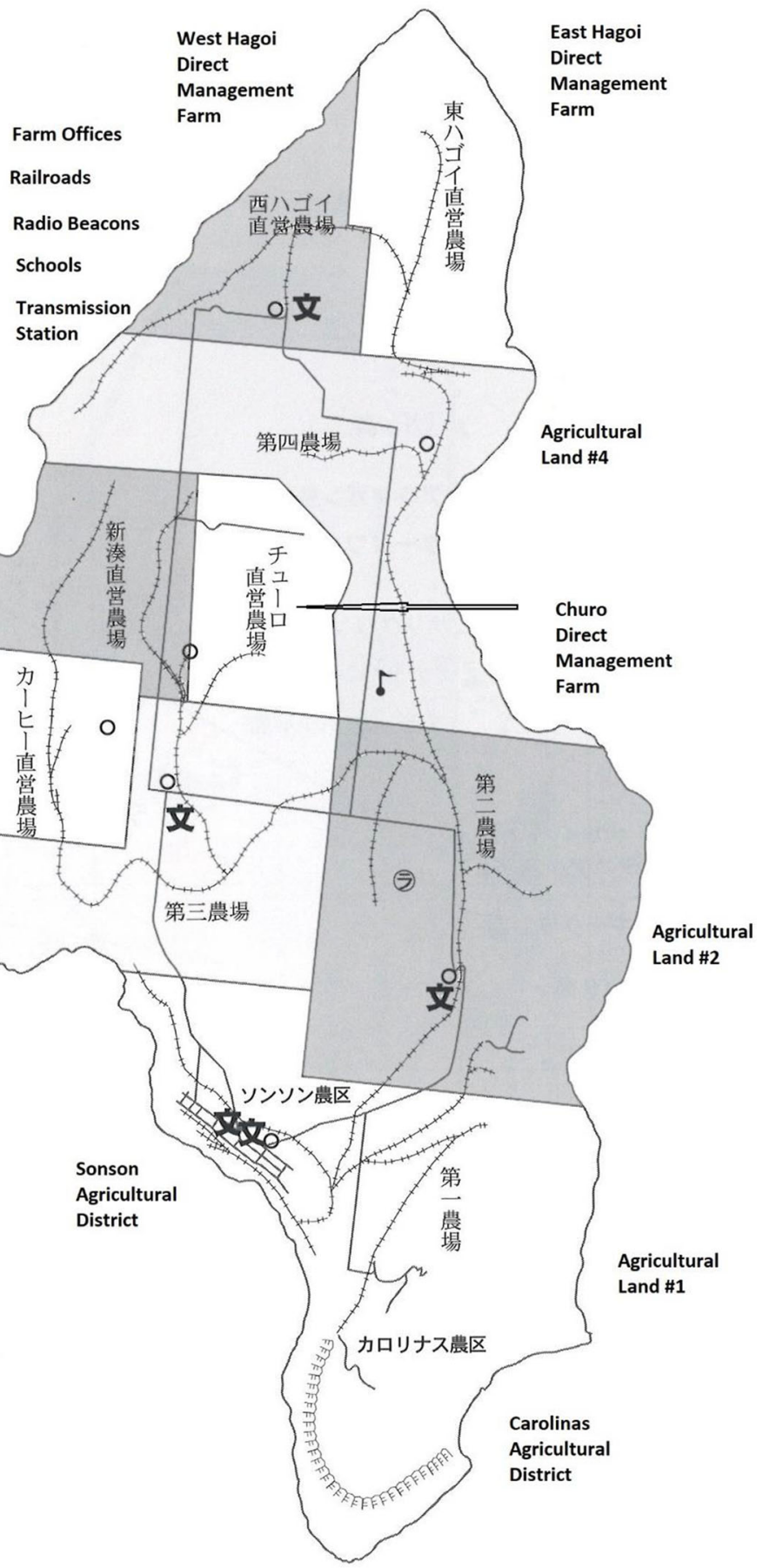

Fig. 10 Tinian Direct Management Farms and Agricultural Lands [caption not translated] (Okinawa Culture Development Association 2002:4). Translated from Japanese 


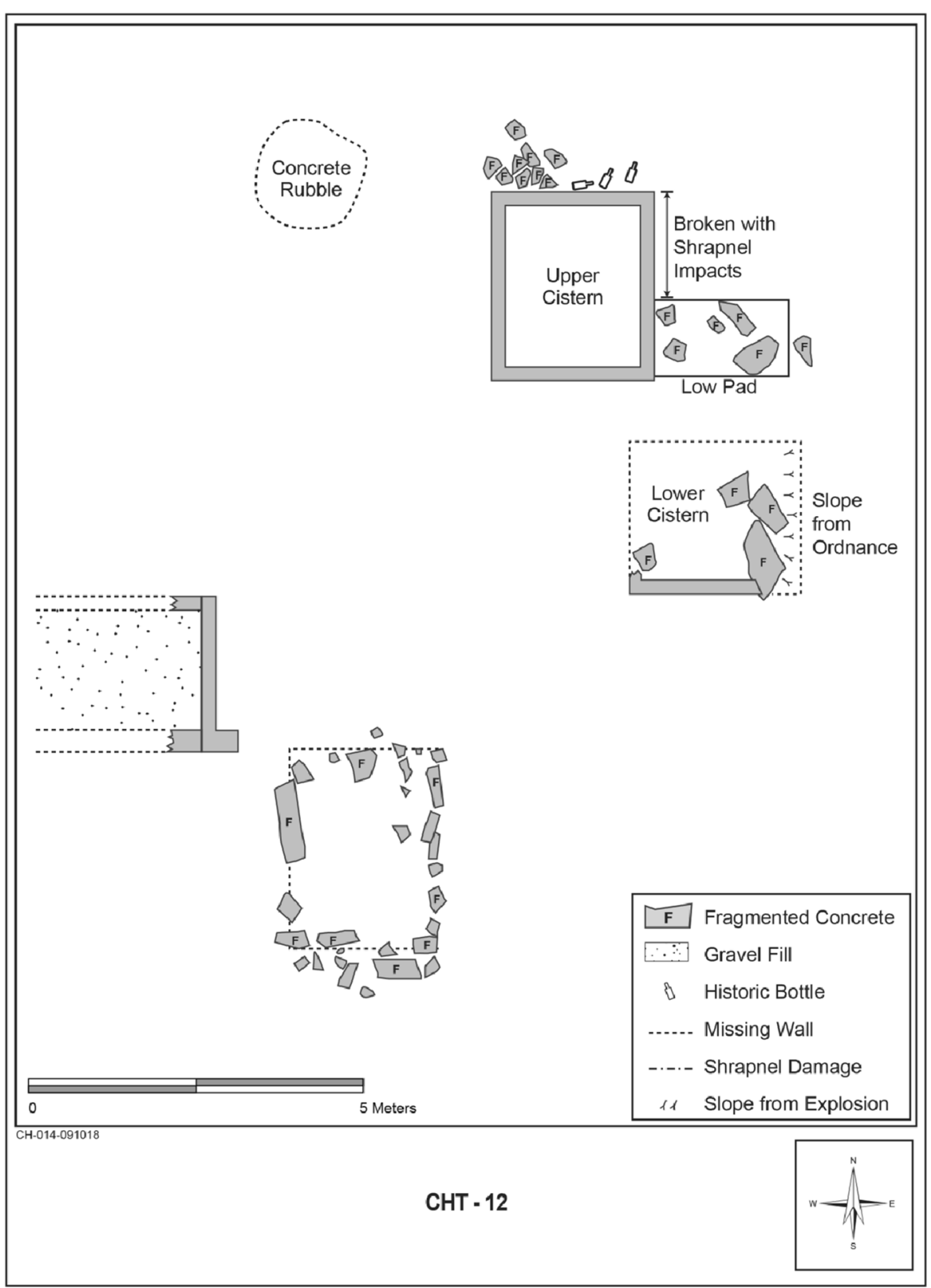

Fig. 11 Okinawan Farmstead Site Map CHT-12 Carolinas Plateau (Jones et al. 2019)

Soil in the area was generally very shallow, resting just above limestone bedrock, and would have been insufficiently deep to grow many deep root vegetables. The stone-lined enclosures may have served to contain soil borrowed from the adjacent pits, forming a low raised bed that could be cleared and maintained. The irregular holes found in association with the enclosures are interpreted as borrow pits, where existing 


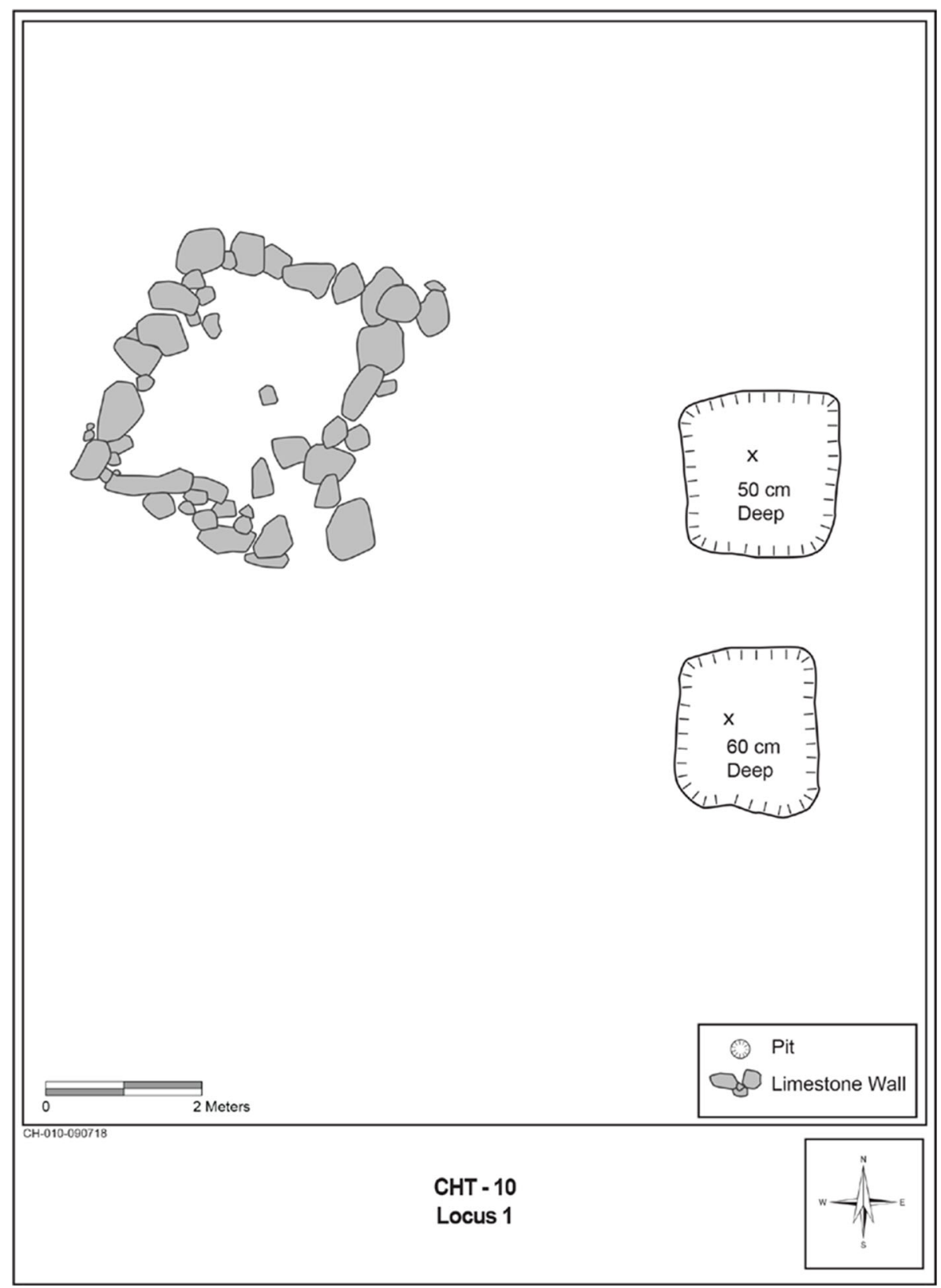

Fig. 12 Okinawan Garden Plot Site CHT-10 Carolinas Plateau (Jones et al. 2019)

soil was removed in order to deepen the soil profile in the enclosed space. Three loci were recorded within 10-20 m of each other, forming a north-south string of garden plots. Large concrete cistern and pad complexes located approximately $150 \mathrm{~m}$ east of the garden plots speak to occupation of the area, as do remnant fields filled with sword 


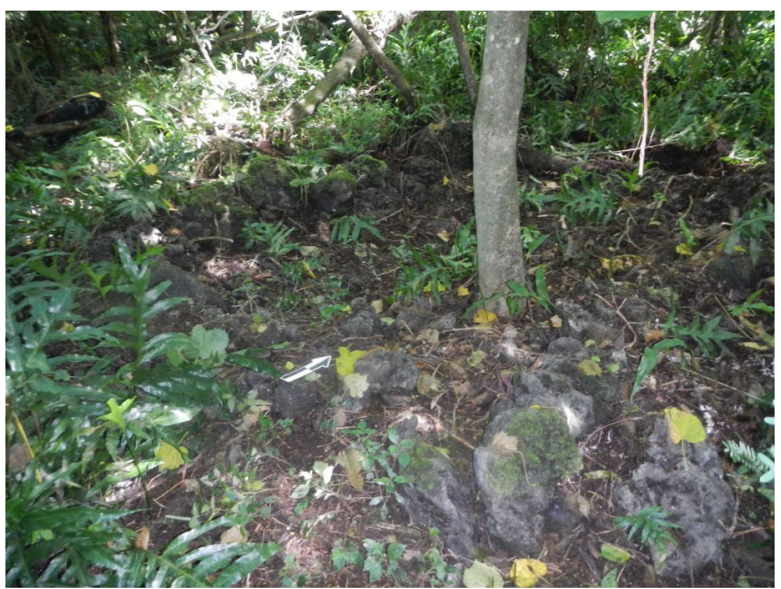

Fig. 13 Okinawan Garden Plot Site CHT-10 Carolinas Plateau (Jones et al. 2019)

grass and the presence of cultivars such as calamansi (Citrofortunella microcarpa) and papaya (Carica papaya), which were noted in the area.

\section{Okinawan Refuges and Military Defenses}

WWII civilian Okinawan refuges and hastily built Japanese defenses in rural settings (Fig. 14) were also found in cliff lines beyond the edge of sugarcane field systems and farmsteads, most with some evidence of being defended by Japanese military in the last days of the battle on the southern Carolinas plateau (Jones et al. 2019). Most low cobble walled refuges appeared constructed in haste with minimal attempt at camouflage, though several were situated overlooking limited access points to the plateau, suggesting Japanese military and not civilian security considerations.

Many of these hastily constructed walled refuges in limestone cracks and under boulders contained artifacts left behind by civilian Okinawan farmers and their families (Figs. 15 and 16), as well as by Japanese soldiers (Jones et al. 2019). Beer and sake or shoyu bottles, some used for water storage to judge from their necks broken by American soldiers, often littered these refuges. Sometimes present were flanged metal rice cookers, ceramic serving and eating vessels, and metal food trays of military issue. Also present in some such refuges such as site CHT-14 were Japanese military issue clothing, canteens pierced by American bayonets to preclude further use, helmets, grenades, and bullets from rifles and machine guns (Fig. 17), plus human remains abandoned in the last moments of combat.

\section{Discussion}

As has been noted by earlier examinations of Japanese archival records and photographs of the early twentieth-century Okinawan diaspora to the CNMI, "Tinian town is a good illustration of a comprehensively planned Japanese colonial sugar town, comprising all the key elements found in Garapan and Chalan Kanoa [Saipan] but in 


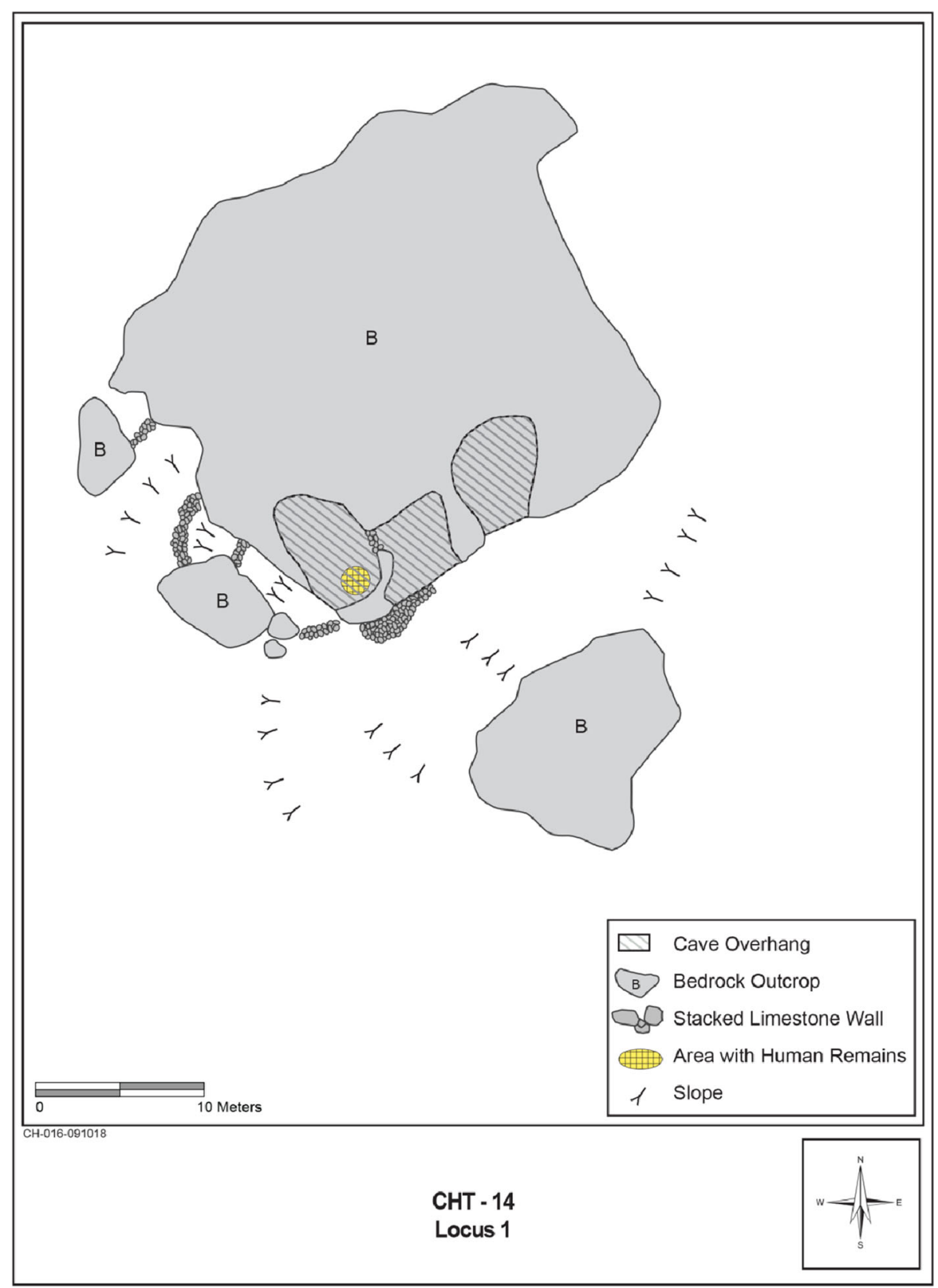

Fig. 14 Okinawan Civilian and Military Refuge Site CHT-14 Carolinas Plateau (Jones et al. 2019)

a more compact arrangement" (Ono et al. 2002:338). Moreover, the archaeological remains of the diaspora today also demonstrate that virtually the entire island of Tinian was a planned cultural landscape as were Saipan, Rota, and to a lesser extent Pagan, with the diaspora orchestrated by the NKK in close coordination with the colonial government of Japan and the Okinawan Prefecture. 


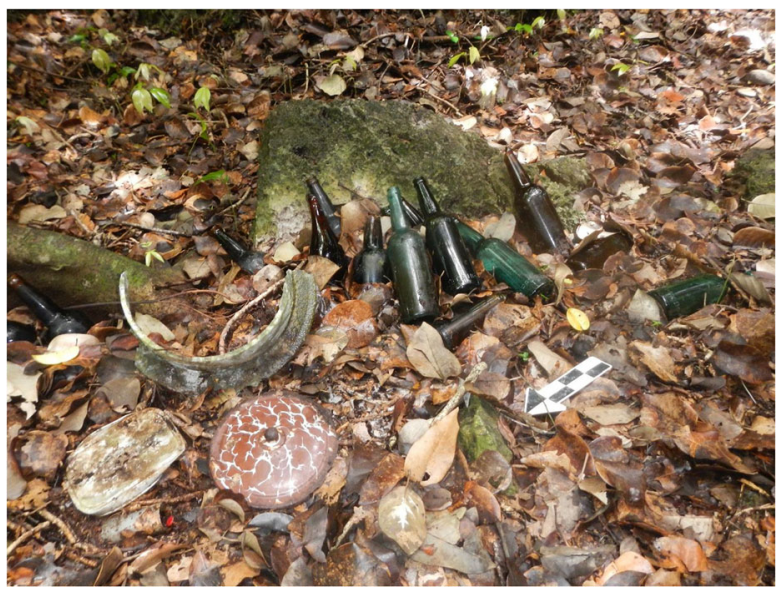

Fig. 15 Okinawan Civilian and Military Refuge Artifacts Site CHT-14 Bottles, Rice Cooker, Metal Tray, and Ceramic Top Carolinas Plateau (Jones et al. 2019)

In comparison to Tinian, the capital of colonial administration in the Marianas was located in the sprawling town of Garapan on the west coast of Saipan (see Fig. 1), situated close to the small commercial port of Tanapag to the north and its mixed Chamorro and Carolinian community (Russell 1984). The headquarters of the Saipan NKK and its sugar refinery and distillery to make "Genuine Old Scotch Whiskey" were located to the south of Garapan in the community of Chalan Kanoa (Farrell 2016) nestled between the coastal lagoon and a shallow lake Susupe. This Japanese sugar company town was likely modeled on one built in Minami Daito in the Ryūkyū Islands north of Okinawa (Ono et al. 2002), with orderly streets and modern residential compounds separating executives, management, and labor while supporting 3,400 mostly immigrant employees by 1935. Also provided were tennis courts, NKK clubhouses, a company kindergarten, and a NKK store where employees could buy household products on credit or chose to enter Garapan to shop via bicycle along

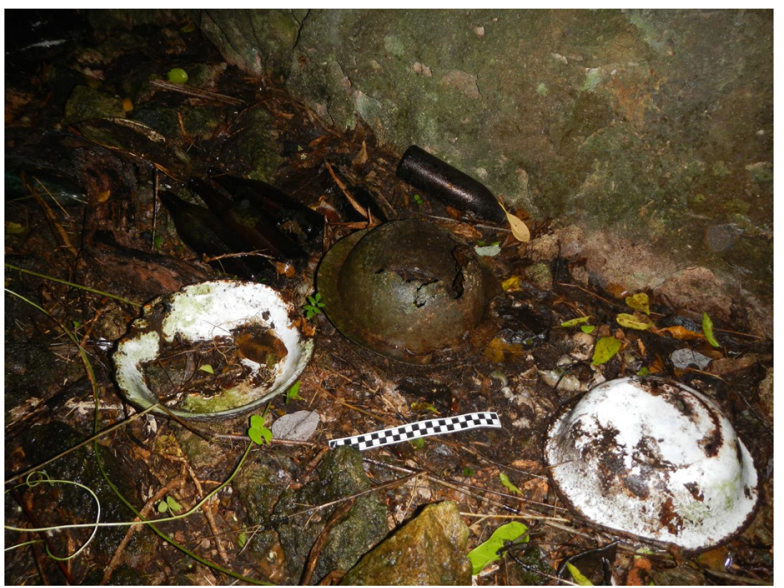

Fig. 16 Okinawan Civilian and Military Refuge Artifacts Site CHT-14 Bottles, Rice Cooker, Porcelain and Enamel Bowls Carolinas Plateau (Jones et al. 2019) 


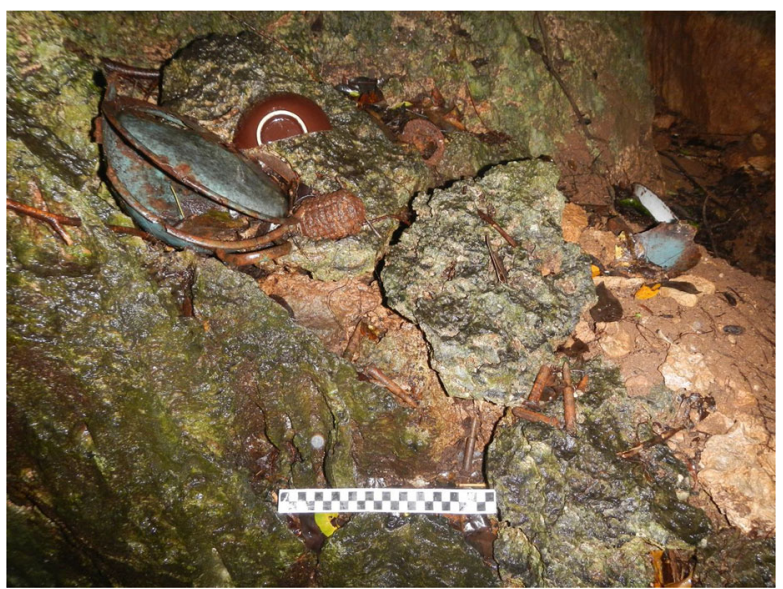

Fig. 17 Okinawan Civilian and Military Refuge Artifacts Site CHT-14 Cooking and Serving Ware, Grenade, and Bullets Carolinas Plateau (Jones et al. 2019)

shaded walking paths. A narrow-gauge train brought the island's sugarcane harvest to the refinery from three large plantations and the Okinawan labor to and from the fields daily (Sugar King Foundation 2017).

While the twisted remains of the Tinian sugar refinery are under dense jungle today after fierce WWII shelling and combat in 1944, some idea may be gained by comparing it to the NKK refinery in Songsong Village on the island of Rota to the south (see Fig. 1). Songsong or Rota Town was a smaller village (Dixon 2004) comprising all the key elements found in Garapan and Chalan Kanoa, but in a more compact arrangement like Tinian Town, situated on a narrow isthmus connecting the main island to a much smaller limestone promontory. The Rota sugar plant was completed and operational in 1936 after five years of survey for the cane plantations on the plateaus above where the farmers resided (Higuchi in Dixon 2000). The remains of a portion of the sugarcane railway, its loading docks in the fields, masonry bridges across streams, and associated Okinawan farmstead remains have been recorded at some distance from the sugar refinery (Dixon 2014) but are not interpreted in situ today. The island of Rota was frequently bombed but never invaded during WWII until after the surrender.

The Japanese population living in the town of Shomshon on the smaller volcanic island of Pagan located well north of Saipan (see Fig. 1) remained low in numbers until the construction of military defenses and a runway called "place for drying fishing nets" in the early 1940s (Higuchi in Athens 2009). By then the town could boast stores to sell pastries and tofu, plus a coffee shop, brothel, elementary school, workers housing, wireless communication facility, police station, weather station, Shinto shrine, and a small wharf at Pontan Bandera (Dixon et al. 2014). It is also by that time that Pagan was no longer just an idyllic stepping stone in the East Asia Co-Prosperity Sphere, but clearly an integral part of the "Absolute National Defense Sphere" whose residents were expected to sacrifice all to protect the Japanese homeland (Price and Knecht 2012). Sugarcane was never introduced on a plantation scale, so the population barely exceeded 2000 Japanese military and fewer Chamorro and Carolinian civilians, 
plus 1000 Okinawan bonito fishermen by WWII, when the island was bombed but never invaded, until after the war.

The initial sugarcane industry with early plantation towns in Taiwan and Okinawa incorporated aspects of urban planning into a design based on observations by Japanese engineers of European and Hawaiian plantations in 1896 and then 1905, and a $76 \mathrm{~cm}-$ gauge railroad as used on Maui. "Where the early model of Hawaiian housing came from at the turn of the twentieth century still remains to be investigated and some resemblance with contemporary plantation housing of the southern states of the US mainland is noticeable" (Ono and Ando 2007:182). It should be mentioned here with that model in mind, that after being awarded a scholarship from the Japanese Ministry of Agriculture and Commerce in 1903, a young Haruji Matsue (see Fig. 2) attended the agricultural program at Louisiana State University associated with the Audubon Sugar School in New Orleans. On his way home to Japan he visited a sugar company in Pennsylvania to learn how to make sugar cubes, then apprenticed briefly at the Spreckels Sugar Company in Hawaii (Ballendorf 1997), returning home with a degree in 1907.

As has been stated elsewhere (Dixon and Tuggle 2014:ii), this built environment on Tinian and the other NKK islands could only have been constructed by the large-scale diaspora of tens of thousands of Japanese citizens from Okinawa and elsewhere. But while the land and building materials were provided by NKK, the labor and the design of individual farmsteads likely reflected the agency and self-sufficiency of the Okinawan immigrants themselves. This idyllic way of life came to an abrupt halt by the spring of 1944 , however, when maritime commerce and communication with mainland Japan ended and military self-defense became a higher priority than civilian survival from bombing raids. Rudimentary civilian refuges and military defenses in the cliff lines near the Carolinas plateau farmsteads in southern Tinian, and the domestic cooking artifacts and beverages discarded by the occupants mixed with their remains, bespeak the desperation and horror in which combat took place for all. Rural farms, resources, livestock, labor, and railroads were coopted for military priorities, civilian war casualties were high, and survivors ended up in American detention camps until repatriation in 1946.

\section{Conclusions}

While many if not most of these Okinawan individuals and families presumably emigrated for their own personal betterment well before WWII, their eventual usefulness in constructing military defenses on the same islands did not go unnoticed by the Japanese government, which helped finance this unprecedented growth in the shadow of a looming global conflict. Tariffs on imported sugar and other raw materials produced outside the Northern Mariana Islands certainly underwrote what was also a useful policy to reduce overpopulation in Okinawa and elsewhere in rural Japan. Longterm geopolitical objectives in Micronesia were not likely overlooked by the military and imperial government, however, nor by NKK. The letters painted on the three molasses tanks next to the Tinian sugar refinery (see Fig. 3) declaring "Prayer for the War Victory" make this proposition self-evident. 
Japanese sources accessed in the University of the Ryūkyūs and Urasoe City libraries in Okinawa contained oral accounts from former occupants of Tinian as synthesized above and cited in the references below. However, these sources did not contain photographs of vernacular architecture occupied by the Okinawan farmers in rural settings nor their labor in the fields or at home, the majority of photographs being of urban Tinian Town and its then modern amenities, presumably a higher matter of pride to the NKK. Archaeological excavations within the urban footprint of Tinian Town are today prompted by infrastructure improvements and do not generally target Japanese-era architectural remains. In contrast, subsurface excavations of rural pre-war farmsteads and WWII military defenses are rarely triggered when these sites can be avoided; survey and recording being the preferred option for preservation. Archival photographs, maps, and translated text located in Okinawa are therefore of increasing value to scholars and cultural landscape managers in the Northern Mariana Islands, especially after natural disasters such as Typhoon Yutu and now Covid 19.

Data Availability Statement Archival photographs from Tinian are accessible to the public upon request in volumes cited below at the Urasoe Public Library (https://urasoecity.fandom.com/wiki/Urasoe Public Library) and the library of the University of the Ryūkyūs (https://librarytechnology.org/library/11325). Archaeological field photographs from Tinian are accessible to the public upon request in the Cardno GS technical volume cited below at the Commonwealth of the Northern Mariana Islands Historic Preservation Office (www.dcca.gov.mp/hpo-historic-preservation-office).

\section{References}

Asato, S. (2002). Kyū nan'yō guntō teniantō imin no kikitori kiroku - Okinawa hontō goekuson shusshin asato uto no baai - [Records of hearing surveys from emigrants in Tinian Island in the former Nan'yō Archipelago - the case of Asata Uto from Goeku Village in Okinawa Island -] (旧南洋群島テニアン島移 民の聞き取り記録- 縄本島越来村身安里ウトの場合-). Shiryō henshū shitsu kiyō [Journal of the Historical Documents Edition Room] (史料編集室紀要) 27: 97-106.

Athens, S. (2009). Final Archaeological Surveys and Cultural Resources Studies on Guam and the Commonwealth of the Northern Mariana Islands in Support of the Joint Guam Build Up Environmental Impact Statement Volume III-I: Tinian Narrative Report and Volume II-I: Saipan, Sarigan, and Pagan Narrative Report. International Archaeological Research Institute, Inc., Honolulu.

Ballendorf, D. (1997). Colonial Japan in Micronesia. Manuscript on file, Micronesian Area Research Center, University of Guam, Mangilao.

Bowers, N. (1950). Problems of Resettlement on Saipan, Tinian, and Rota, Mariana Islands. Pacific Science Research Board and National Research Council, Ann Arbor, Michigan.

Denfeld, C. (1983). A Field Survey and Historical Overview, North Field, Tinian. Division of Historic Preservation, Saipan, CNMI.

Dixon, B. (2004). Archaeological patterns of rural settlement and class on a pre-WWII Japanese plantation, Tinian, Commonwealth of the Northern Mariana Islands. International Journal of Historical Archaeology 8(9): 281-299.

Dixon, B. (2014). Transforming the diaspora: an early twentieth century Japanese railroad on Rota, Commonwealth of the Northern Mariana Islands. Pan-Japan: The International Journal of the Japanese Diaspora 11(1/2): 94-120.

Dixon, B., Garrigue, A., and Mukai, T. (2014). Archaeological Test Excavations in Support of Kubasaki High School Replacement Project, Marine Corps Base Smedley D. Butler, Okinawa, Japan. Cardno TEC Inc., Guam, and ARCGEO Inc., Okinawa.

Dixon, B. and Tuggle, D. (2014). The Japanese diaspora in Micronesia: its archaeological context: introduction. Pan-Japan The International Journal of the Japanese Diaspora 11(1/2): i-ix.

Farrell, D. (2012). Tinian: A Brief History. Pacific Historic Parks, Honolulu. 
Farrell, D. (2016). Saipan: A Brief History. Micronesian Productions, Tinian.

Higuchi, W. (1998) Appendix A. Tinian Power Plant Proposed Sites: A Historical Overview. In Moore, D.R., R.L. Hunter-Anderson, E.F. Wells, and J.R. Amesbury. Archaeological and Historical Research at the Tinian Power Plant Site, San Jose Village, Tinian Island, Commonwealth of the Northern Mariana Islands. Prepared for Telesource Inc. Micronesian Archaeological Research Services, Mangilao, Guam.

Higuchi, W. (2000) Interview with Jiro Takemura, in B. Dixon, Archaeological Survey of Rota Highway 100, Island of Rota, Commonwealth of the Northern Mariana Islands. International Archaeological Research Institute, Inc., Honolulu.

Iha, O. (2006). Okinawa, saipan no kurashi [Life in Okinawa and Saipan] (沖縄、サイパンのらし). In Chatan Town (ed.), Heisei jūhachi nendo senji taikensha kōwakai [2006 Year War Survivors Conference Series] (平成18年度戦時体験者講話会). http://www.chatan.jp/choseijoho/heiwagyosei/senjitaikensha/h18_ senjitaikensha/1.html

Iitaka, S. (1999). Nippon tōchika mariana shotō ni okeru seitōgyōno tenkai: nan'yō kōhatsu kabushikigaisha no okinawa kenjin rōdō imin dōnyū to genchi shakai no henyō [The development of suger (sic) industry in the Mariana Islands under Japanese rule: the introduction of Okinawa labor immigrants by the South Seas development company and the cultural change in native societies] (日本統治下マリアナ諸島に捛ける製 糖業の展開:南洋興発株式会社の沖縄県人労働移民導入と現地社会の変容), Shigaku [The historical Science] (史 学) 69(1): 107-140.

Ishikawa, Y. (1974). Kaigai imin no tenkai [The expansion of foreign emigration] (海外移民の展開). In Board of Education of Okinawa Prefecture (ed.), Okinawaken shi dai nana kan imin [History of Okinawa Prefecture vol. 7 Emigration] (沖縄県史 第七巻 移民), Board of Education of Okinawa Prefecture, Naha, pp. 204-251.

Ishikawa, Y. (2005). Okinawa ni okeru shutsuimin no rekishi oyobi shutsuimin yōinron [History and theories of emigrants from Okinawa Prefecture] (沖縄県における出移民の歴史及び出移民要因論). Imin Kenkyū [Imigration Studies] (移民研究) 1: 11-30.

Ishikawa, Y. (2011). Kyū nan'yō guntō nihonjin imin no seikatsu to idō - okinawaken shusshin imin no jirei wo chūshin ni - [Life and movements of the Japanese migrants in the former Nan'yō Archipelago essentially based on the examples of migrants from Okinawa Prefecture] (旧南洋群島日本人移民の生活と移 動一沖縄県出身移民の事例を中心に). Imin Kenkyū [Imigration Studies] (移民研究) 7: 123-142.

Jones, R., Welch, D., Dixon, B., and Nelson, I. (2019). Final Report: Archaeological Survey of 50 Hectares in the Carolinas Heights Region, Tinian, Commonwealth of the Northern Mariana Islands. Cardno GS, Boise and Guam.

Matayoshi, Y. (2009). Nan'yō imin no katari ni miru "iminzō" - saipan ni watatta okinawakei nisei no raifu hisutorii kara - [The image of migrants as seen in the stories of Nan'yō migrants - from the life history of a second generation Okinawan who had crossed to Saipan - ] (南洋移民の語りにみる「移民像」 ーサイパンにつた沖縄系2世のライフヒストリから-), Imin Kenkyū [Immigration Studies] (移民研究) 5: 87112.

Matsue, H. (1932). A Record of Ten Years of Development in the South Seas, Nan'yo Kohatsu K. K, Tokyo.

Myers, M. and Peattie, M. (1984). The Japanese Colonial Empire, 1895-1945. Princeton University Press, Princeton, NJ.

Okinawa Culture Development Association, Archival Management Historical Materials Edition Office. (2002). Okinawa Prefecture History Historical Materials 15 (1 on 2 volumes), Photographic Records related to the Former Nanyo Archipelago (Vol. 1) Contemporary Period 4, Okinawa Prefecture Board of Education: Naha.

Ono, K. and Ando, T. (2007). A study of urban morphology of Japanese colonial towns, in Nan'yo Gunto, part 3: origins of the model Japanese sugar plantation town in Taiwan. Journal of Architecture, Planning and Environmental Engineering 612:177-184.

Ono, K., Lea, J., and Ando, T. (2002). A study of urban morphology of Japanese colonial towns, in Nan'yo Gunto, part 1: Garapan, Tinian, and Chalan Kanoa in Northern Marianas. Journal of Architecture, Planning and Environmental Engineering 566:333-339.

Peattie, M. (1988). Nanyo The Rise and Fall of the Japanese in Micronesia 1885-1945. University of Hawaii Press, Honolulu.

Price, N. and Knecht, R. (2012). Peleliu 1944: the archaeology of a South Pacific D-Day. Journal of Conflict Archaeology 7(1)5-48.

Russell, S. (1983). Rising Sun over the Northern Marianas: Life and Culture under the Japanese Administration (1914-1944). CNMI Division of Historic Preservation, Saipan.

Russell, S. (1984). From Arabawal to Ashes: A Brief History of Garapan Village, 1818 to 1945. CNMI Division of Historic Preservation, Saipan.

Russell, S. (1995). Tinian: The Final Chapter. CNMI Division of Historic Preservation, Saipan. 
Sugar King Foundation. (2017). A Historical Portrait of Haruji Matsue. http://www.sugarking.org/hmFrame. html

Tuggle, D. (2014). The archaeological landscape of Japanese era Tinian, Mariana Islands. Pan-Japan The International Journal of the Japanese Diaspora 11(1/2): 74-115.

Tuggle, D. and Higuchi, W. (2012). Concrete Terraces and Japanese Agricultural Production on Tinian, Mariana Islands. First Marianas History Conference, Guampedia.

Welch, D. and Bodner, C. (2014). Japanese farmsteads in southern Tinian: archaeology, history, and recollections. Pan-Japan The International Journal of the Japanese Diaspora 11(1/2): 121-164.

Publisher's Note Springer Nature remains neutral with regard to jurisdictional claims in published maps and institutional affiliations. 